\title{
Psychotherapy in the Service of the Lonely
}

\author{
Ami Rokach* \\ Ph D, York University, Toronto, Canada, Centre for Academic Studies, Israel
}

Submission: April 22, 2018; Published: April 30, 2018

*Corresponding author: Ami Rokach, Ph.D, York University, Toronto, Canada, Centre for Academic Studies, Yehuda, Israel, Email: arokach@yorku.ca

Abstract

Both loneliness and psychotherapy have been well researched and described. The present paper examines the interaction between them; the salient features of psychotherapy, the needs of the lonely, and the use of the therapeutic process in helping the lonely survive and emerge from their ordeal, emotionally strengthened and spiritually enriched

Keywords: Level Of Internet Use; Students; Selected College.

\section{Introduction}

\section{The Therapeutic Relations in Psychotherapy}

In his book The Road Less Travelled, Peck [1] suggested that "Entering psychotherapy is an act of the greatest courage" (p. 53). Psychotherapy, at least in the Western culture, is associated with emotional pain and "disturbed" patients (or clients) of psychologists and psychiatrists. Normally, psychotherapy does involve a trained and, hopefully, skilled therapist who attempts to help the clients alleviate their problems. However, the therapist also seeks to contribute to his client's further growth and development through the interaction and relationship that develops between them. The therapeutic relationship is so central to the therapist's practice, that its overall form and structure is often accepted without seriously considering the idea that "the relationship may have a structure beyond its temporal, physical and financial boundaries" Schamess [2]. It unfolds according to its own dynamics and the roles of its participants, and over time, the bond that develops between client and therapist becomes intimate and close, as well as therapeutically beneficial.

Whereas in non-therapeutic relationships both participants are open about themselves and vulnerable (a mutuality which serves to strengthen their bond), according to Schamess [2] only the client is expected to do the "risky revealing" in psychotherapy. That being said, it does not have to diminish form the intimacy between the two participants. The therapist can greatly contribute to that intimacy by being truly interested in and caring about the client, and by being genuine, showing warmth and fully accepting the client. Psychotherapy, not unlike non-therapeutic intimate relationships is bi-directional, though the participants' roles and behaviours differ. In non-therapeutic relationships, we can find relationships where participants promote dependence in their partners, or engage in a leader-follower pattern of interaction, while in other relations partners may encourage their loved one to grow and develop. In psychotherapy, the therapist is expected to structure the relationship in such a way that it aims, first and foremost, to help the client alleviate his problems. We should point out that during psychotherapy some of the therapist's needs are met as well, despite it being focused on the client. This may include increased esteem, learning about human nature and behaviour, being seen helpful, and being financially remunerated Rokach [3] While it is assumed that the therapist is a reasonably secure person and that his life is not bleak or desolate, the client on the other hand may be [and frequently is] a lonely and alienated individual. When they interact, the therapist attentively listens to the client, sympathizes with him, and endeavours to understand how he feels; therapists are supposed to always remain even keeled and does not turn his back on the client because he cannot stand the outpouring. In other words, the therapist may be construed as an almost ideal confidante by the client. Small wonder then that often times the emotional feelings involved in therapy rise to a crescendo where either or both parties may be frustrated by the fact that the hour has to end and that both parties must go on to their private lives, perhaps not to see each other for an entire week Klopfer [4].

Intimacy, while welcomed in therapy, may become an issue if the therapist and client are of the opposite sex Rokach [3]. It is not unusual--or unexpected--to find a female client who glamorizes her male therapist (or vice versa) and fantasizes about him becoming her lover. She may then offer herself to him sexually, directly and bluntly or covertly, in an attempt to deepen their intimacy and through it receive increased attention, acceptance, approval, and closeness to him (see also Holroyd, Lerman, Forer \& Greenberg, 1983). The traditional psychoanalytic model refers 
to it as transference, while a therapist who has similar feelings toward his client is said to be experiencing counter-transference. I believe that it may be a mistake to attribute all of the client's sexual daydreams and emotional responses to his or her neurotic distortion of the therapist-client relationship see also Klopfer [4]; Rogers [5]; Szasz [6]. It is suggested that what the client feels and thinks about the therapist is not as unreal as the psychodynamic approach maintains. Though some of the client's feelings toward the therapist may be of a transference nature, it is quite reasonable to conclude that the feelings the client has for the therapist are genuinely directed at the human being behind the helper's title. Lonely clients feel their loneliness to be painful and yearn to escape from behind the walls they feel surrounded by Peck [1]. And, as many have discovered, "the experience of falling in love allows us this escape--temporarily-from the place in we may feel confined to. The essence of the phenomenon of falling in love is a sudden collapse of a section of an individual's ego boundaries, permitting one to merge his or her identity with that of another person" Peck [1] p. 87. It is, indeed, possible for therapist and client to genuinely fall in love with each other as a result of true feelings of love, as a consequence of transference, or possibly as a combination of the two" Klopfer [4] p. 39.

\section{The Therapist}

Commenting on the essence of psychotherapy, and referring to the role the therapist plays in the change and growth of the client, Peck [1] noted that it is impossible to truly understand another without letting that person within yourself. In my experience as a clinical psychologist, that process affects not only my clients, but me as well. As a therapist, I am have the very privilege of being allowed into other people's worlds. I am invited to become closer to them than they would, perhaps, allow even their most intimate friends. Consequently, I witness their pain and assist them in addressing it. The client, naturally, needs to be committed to therapy, for it to succeed. For the duration of therapy the therapist is required to make the same kind of commitment to the client. This commitment entails understanding and supporting whatever stage the client is at, and he must be willing to grow and learn from the client. Psychotherapy requires courage of the therapist; courage to risk change, make interpretations, suggestions and observations; courage to extend oneself, and courage to be, at times, different and unconventional. Most importantly, the therapist must strive to nurture the therapeutic relationship by making room for the client within himself. And that very commitment is, in my experience, one of the most rigorous, demanding and all-consuming requirements a therapist has to fulfill Rokach [3]. Although I do not care for all my clients in an identical manner, I have never yet treated anyone who I did not care about or for. At times, I am blessed to work with those I consider unique; people whose characteristics I highly value, and whom I would certainly choose to befriend had we met "on the street". However, psychotherapy is a unique alliance which is confined to a specific time and place, and which is governed by strict ground rules. Its very existence depends on, and focuses upon the client.
The therapeutic relationship is established and carried out in order to help the client and not to fulfil the therapist's needs. Consequently, although I may yearn to remain a close friend with a client, to see that person grow and develop, and thus continue to enjoy the enriching relationship which I had with him or her, I cannot do so. It has been rare that I have kept in contact after therapy was terminated, and if I do so, it was on a casual basis, rather than as a close friend. I read once that every love relationship involves therapy, and every psychotherapy includes love. Peck [1] observed that "The essential ingredient of successful, deep, and meaningful psychotherapy is love” (p. 173). Love, as we understand it, calls for a continuous and close alliance. However, being a therapist means being ready to suffer, sacrifice, and give of oneself, not only while sharing the client's pain and sorrow during therapy, but also by not submitting to the heart's desire to continue and enjoy the company of a person I became close to in my office.

Much has been written about therapist burnout i.e. Figley [7]; Bagel [8]; Bride [9]; Rothschild [10]; Steele et al. [11]. However, very little, if anything, has been written about psychotherapy as a lonely journey for the therapist. I find it difficult, and at times painful, to say goodbye to a client which, most probably, I will never see again. No other relationship is so teasingly painful. In therapy, two people interact so closely, growing and learning from one another, only to depart when the relationship is ripe for a more balanced and enriching experience. Over the 40 years that I have worked with clients, I have had two "wishes" concerning my clients. One was to let them know that I would like to remain their friend following completion of therapy. In so doing, however, I would selfishly declare that I am now focusing attention on my needs after catering mainly to theirs. In other words, I would be saying, I would like to be your friend and remain so not necessarily because it is therapeutic and beneficial for you, but because I like and value you, and because this is something that I want and need. As I mentioned earlier, I have yet to follow through. My other 'wish' is quite different, and has to do with wishing that I could offer psychotherapy in a detached, mechanical way so as to prevent closeness and mutual fondness from forming. This being so far removed from the essence and spirit of psychotherapy, and from the manner in which I practice it, that I could not possibly realize that wish either, nor would I want to. That means that the profession in which I have chosen to specialize can be a painfully lonely one.

\section{Helping the Lonely}

Since loneliness is not a unidimensional phenomenon, treatment is frequently multifaceted as well. For example, loneliness that follows the death of a loved one often requires resolution of the grief process as a prerequisite to the alleviation of loneliness and formulation of new social relationships Lopata et al. [12]; Rokach [13]. On the other hand, loneliness which follows a divorce may necessitate treatment that is initially directed at feelings of interpersonal inadequacy and insecurity and only then can the loneliness be addressed Weiss [14]. "Many of the problems 
and much of the pain I felt came from trying to resist my loneliness. The moment we begin to build a wall against it, we have already lost... before we can look at our loneliness, we must stop trying to resist it. We must stop blaming husbands or wives, children or bosses for our feelings of loneliness and [the] alienation in our lives. Schultz [15] p. 169. This quote describes precisely what many lonely clients do; they run away, hide or deny their loneliness, ashamed to admit that they are in pain, or frightened of the stigma which is attached to loneliness Moustakas [16]; Rokach $[17,18]$. However, if they do finally talk about their loneliness, they often go on a rampage, blaming everyone around them for it. My purpose is to, initially, empower the client to recognize and admit that he is lonely, his loneliness, and take full responsibility for it. Once that has been done through nurturing within the therapeutic relationship, the client is on her way to lessening the pain.

Having been, once, asked how do I help the lonely, I replied that I see myself as a father or a friend who is attempting to teach a child to swim while the child is terrified to even approach the water. That analogy, for me, encapsulated the trust the child must first have in order to place his hand in his father's. The courage the child needs to approach the water, and the effort they will both need to invest in order to teach the child the series of co-ordinated movements that will allow him to float and move in whatever direction he chooses, and eventually, be able to swim. Friedman [19] observed that while paying attention to the community one lives in, is part and parcel of what sociologists and social workers, psychologists are commonly trained in the language of individual self-interest, and thus focusing on the client's community ties and belonging may pose a challenge. Examining the client's ties to the community and helping to cultivate a strong sense of belonging are important, but often overlooked therapeutic goals when that therapy is offered by psychologists. To begin with, it should be mentioned, reminded us Friedman that the therapeutic alliance can serve as a way of belonging which can be nurtured and developed. Especially for people who experience difficulty in connecting with others, and who are lonely, the experience of belonging that takes root in therapy, may be a significant achievement for them and be further extended to their lives outside of therapy. Thus, a close, intimate therapeutic alliance is the cornerstone of a fruitful therapy, and a way to help the client feel belonging and a connection to a caring individual. Doherty [20] maintained that therapists can educate clients about the need for a community by providing an accepting and supportive connection in the therapy room. He, eloquently declared that "there is no fundamental contradiction between pursuing personal needs and promoting the welfare of the community. When we promote clients' positive involvement in the community, we promote their own well-being as well" (p. 100). Friedman argued, with a lot of conviction that what is needed is a sort of a holistic approach which together with helping the client explore his inner self also be aware of the outer realm.

Therapy is seldom neutral, and moreover it reflects and reproduces cultural norms. Cushman [21], thus, argued that by valorising the isolated individual, we may actually strengthen the problems that the client is struggling with. Since the therapy we offer, and our interactions with the client reflect our values, beliefs, and background - it is imperative that psychotherapists become aware and adopt the view that belonging to and building a community is a fundamental ingredient of well-being Blow and Timm [22]. Attending psychotherapy has not been condoned in the North American society for a long while. At the dawn of the 20th century it changed and many more are attending therapy and hiding it less. And still, therapy is offered in confidentiality to the individual, the couple or the nuclear family, but the rest of the community is not represented except by the dialogue between client and therapist. Morgan [23] indicated that this point is addressed by Narrative therapists who encourage their clients "to re author their lives" (p. 2) in order to create newer and more appropriate 'stories' which may include or even focus on one's community and connections. At times, family members, friends or even work colleagues may be invited into the therapy sessions to celebrate the client's accomplishments and or to simply bear witness to the creation of new stories Freeman and Combs [24].

While the therapeutic relationship has been established, strengthened, and is supportive and empowering of the client, and when working with individuals, we address the pain that one feels being lonely, especially for a long time, and feeling deeply stressed and saddened by it. Some clients attempt to distance themselves from the pain and thus tend to supress, or even deny that they are lonely and experience the accompanying negative feelings and cognitions. Facing their loneliness, admitting to themselves that they, indeed, experience it and not run away is the first step. We then attempt to understand the nature of one's loneliness. Is it a transient one influenced by events in the client's life, or is it a chronic, long term, experience that is more troublesome and requires a concerted effort to resolve. The reasons for the loneliness that the client experiences need to be examined and understood, for only then addressing it can be possible. The next step is empowering the client to explore ways to address the loneliness. One approach to that empowering is addressing possible learned helplessness that the client may exhibit, and which prevents a free and courageous exploration of coping strategies. We also highlight the importance of a steady and committed approach, which while it may not always succeed, the client will persevere and have the inner conviction that she can diminish her loneliness and reduce its pain. Some writers Moustakas [25]; Rokach [13,18] suggested that loneliness, just like pain, can be a beneficial force in one's growth and development. Firstly, it directs us to look inwardly (an experience which the extroverted way of life in North America does not encourage), helps us take "personal stock," and evaluate our relationships, goals and our priorities. Loneliness, just like the effects of intense fire on gold, can clear and purify our understanding of who we are and what we want out of life. After experiencing the intense pain of loneliness, suggested Moustakas [25] we may emerge knowing that our resources for coping and living are appropriate, discover new capabilities within ourselves, gain a better understanding 
of the wondrous and beautiful things in nature and the universe, and learn anew to fully appreciate human contact, intimacy, and love. I aim to help my clients realize it and renew their hope for more fruitful human interaction and personal fulfillment. Group approaches to loneliness are, naturally, somewhat different in that the group members can serve as an invaluable source of insight, support, direction, and 'quality control' of the client's journey in addressing his loneliness. Group members, in addition to their support of the client in-group, may also provide friendship outside of the group and encourage the person to explore relationships, friendships, and social intercourse.

Cognitive Strategies: Deshawn Besse [26] reviewed the self-deprecating manner in which the lonely perceive themselves, commonly feeling inferior, unattractive, less socially skilled or overall worthless. One of the consequences of such a point of view is that they tend to perceive the world as negative and others as not trustworthy or accepting Luhmann et al. [27]. Being so unhappy with themselves and their surroundings, the lonely who may want to connect with others, may also be quite hypervigilant which further impacts their negative perceptions of the world and viewpoints about others. These biases, may intensify their loneliness, confirm their negative view of the world and of others Cacioppo and Hawkley [28]. The lonely, consequently, often believe they are helpless and incapable of changing their situation, believing their loneliness is the result of personality characteristics (such as, for example, shyness or low social competence) rather than circumstances and traits that may be more malleable Heinrich and Gullone [29,30]. In light of this vicious cycle, treatment strategies that were suggested included educating the lonely of the connection of their negative and unrealistic thoughts and how they may be contributing to their current situation.

\section{References}

1. Peck MS (1997) The road less travelled: A new psychology of love, traditional values and spiritual growth. NY: A Touchstone Book Simon and Schuster.

2. Schamess G (1983) Client-therapist interactions. In: Rosenblat A, Waldfogel L (Eds.), Handbook of clinical social work, San Francisco, USA, p. 361-381.

3. Rokach A (1986) Psychotherapy: Close encounters of the intimate kind. Contemporary Psychotherapy 16(2): 161-182.

4. Klopfer WG (1974) The seductive patient. In: Klopfer WG \& Reed MR (Eds.), Problems in psychotherapy: An eclectic approach, p. 35-46.

5. Rogers CR (1951) Client-centred therapy. Boston: Houghton Mifflin, pp.560.

6. Szasz TS (1965) The ethics of psychoanalysis. Basic Books, New York.

7. Figley CR (1993) Compassion stress: toward its measurement and management. Family Therapy News 3(16).

8. Bagel M (1993) Helping MFTs in distress. Family Therapy News.

9. Bride BE (2007) Prevalence of secondary traumatic stress among social workers. Social Work 52(1): 63-70.
10. Rothschild B (2006) Help for the helper: The psychophysiology of compassion fatigue and vicarious trauma. New York, Norton.

11. Steele CJ, Macdonald, Schroeder T, Mellor-Clark J (2015) Exhausted but not cynical: burn out in therapists working within Improving Access to Psychological Therapy Services. Journal of Mental Health 24(1): 33-37.

12. Lopata HZ, Heinemann GD, Baum J (1982) Loneliness: Antecedents and coping strategies in the lives of widows. In: Peplau LA, Perlman D (Eds.), Loneliness: A sourcebook of current theory, research, and therapy, p. 310-326.

13. Rokach A (1988) Theoretical approaches to loneliness: from a univariate to a multidimensional experience. Review of Existential Psychology \& Psychiatry 19(2-3): 225-254.

14. Weiss RS (1975) Marital separation. Basic Books, New York, USA.

15. Schultz T (1976) Bittersweet: Surviving and growing from loneliness. NY: T. Crowell.

16. Moustakas CE (1972) Loneliness and love. Englewood Cliffs, PrenticeHall, New Jersey, USA.

17. Rokach A (1990) Surviving and coping with loneliness. The Journal of Psychology 124(1): 39-54.

18. Rokach A (2015) Three of Humankind's Universal Experiences: Loneliness, Illness and Death. In: C. Kowalski, Rokach A, Cangemi JP (Eds.) Loneliness in life: Education, business, society. McGraw-Hill, United States, New York, USA pp. 119-132.

19. Friedman RL (2007) Widening the therapeutic lens: Sense of belonging as an integral dimension of the human experience. A Dissertation submitted to the Wright Institute Graduate School.

20. Doherty WJ (1995) Soul searching: Why psychotherapy must promote moral responsibility. Basic Books, New York, USA.

21. Cushman P (1995) Constructing the self, constructing America: A cultural history of psychotherapy. Cambridge, MA: Perseus Pub 8(1): 165-168.

22. Blow AJ, Timm TM (2002) Promoting community through family therapy: Helping clients develop a network of significant relationships. Journal of Systemic Therapies 21: 1-14.

23. Morgan A (2000). What is Narrative Therapy?.

24. Freeman J, Combs G (1996) Narrative therapy: The social construction of preferred realities. W W Norton, New York, USA.

25. Moustakas CE (1961) Loneliness. Englewood Cliffs, NJ: Prentice Hall, United States.

26. Deshwan Besse R (2016) Loneliness among college students: Examining potential coping strategies and the influence of targeted messages on the likelihood of befriending. Ph D Dissertation, pp: 10161512.

27. Luhmann M, Schonbrodt FD, Hawkley LC, Cacioppo JT (2014) Loneliness and social behaviours in a virtual social environment. Cognition \& Emotion 29(3): 548-558.

28. Cacioppo JT, Hawkley LC (2009) Perceived social isolation and cognition. Trends in Cognitive Sciences 13(10): 447-454.

29. Heinrich LM, Gullone E (2006) The clinical significance of loneliness: A literature review. Clinical Psychology Review 26(6): 695-718.

30. Rokach A, Shaked A (2013) Together and lonely: Loneliness in intimate relationships - Causes and coping. 

(C) This work is licensed under Creative BY DOI: 10.19080/JOJNHC.2018.07.555718

\section{Your next submission with Juniper Publishers} will reach you the below assets

- Quality Editorial service

- Swift Peer Review

- Reprints availability

- E-prints Service

- Manuscript Podcast for convenient understanding

- Global attainment for your research

- Manuscript accessibility in different formats

( Pdf, E-pub, Full Text, Audio)

- Unceasing customer service

Track the below URL for one-step submission https://juniperpublishers.com/online-submission.php 